\title{
Kajian Infrastruktur Ramah Lingkungan Di Perkotaan
}

\author{
Wulfram I. ERVIANTO ${ }^{1 *}$ \\ ${ }^{1}$ Program Studi Teknik Sipil, Fakultas Teknik, Universitas Atma Jaya Yogyakarta, email: \\ wulframervianto@gmail.com
}

\begin{abstract}
The city is an important part of the population as a space to work and socialize with fellow residents who occupy it. Not surprisingly, most of the population moves towards the city to get a more established livelihood. Data shows that the majority of the population living in the villages began to move to the city for various reasons, as indicated by the high rate of urbanization from year to year. One day the village will lose its role as a food barn for residents of the region. On the other hand, infrastructure needs in urban areas tend to increase which results in a decline in natural resources, especially those that are not renewable.To maintain a balance between the capabilities of nature providing various types of natural resources and infrastructure needs that continue to increase from year to year. The right approach is needed by implementing environmentally friendly development. This study discusses environmentally friendly approaches that are implemented in several infrastructures, namely (1) Eco-friendly sea port consisting of 23 important factors, (2) Environmentally friendly airport consisting of eight aspects, (3) environmentally friendly train station that covers three aspects, (a) in the train station environment, (b) along the railroad, through a tree planting greening program that absorbs CO_2 emissions, (c) Appropriate use of water quality and amount, for toilet purposes on trains using used water or rainwater harvested during rain.
\end{abstract}

Keywords: infrastructure; environmentally friendly; urban area

\section{Pendahuluan}

Pengertian kota ditinjau berdasarkan fungsinya dalam wilayah nodal adalah suatu wilayah tertentu yang berfungsi sebagai simpul kegiatan dalam perannya sebagai kolektor dan distributor barang/jasa yang berasal dari wilayah hinterland yang umumnya relatif luas. Upaya-upaya yang dilakukan agar keberlanjutan kota dapat untuk tinggal secara nyaman bagi generasi penerusnya adalah: (a) Meminimalisasi pemanfaatan dan pemborosan sumberdaya yang sifatnya tak terbarukan, termasuk penghematan bahan bakar minyak dan mengelola sumberdaya lain yang sifatnya terbarukan secara bijak. (b) Meminimalkan dan menghindari punahnya aset yang bersifat kultural, historis, dan natural yang tak terbarukan di kawasan perkotaan, antara lain adalah jalur hijau, tempat bermain dan tempat rekreasi. (c) Pemanfaatan dan melestarikan sumberdaya yang bersifat terbarukan, misalnya air bersih. (d) Mengelola limbah padat dan cair untuk diproses menggunakan cara yang tepat agar tidak menimbulkan dampak negatif bagi kehidupan di kota itu sendiri (intra frontier dimension) maupun kehidupan di sekitar kota dan daerah lain (inter frontier dimension).

Upaya pemenuhan kebutuhan bagi generasi saat ini tanpa mengurangi kemampuan untuk memenuhi kebutuhan bagi generasi mendatang dapat dijabarkan menjadi lima pendekatan, yaitu: (a) Persoalan pemanfaatan energi dan menjaga kualitas udara. (b) Pemanfaatan lahan dan ruang terbuka hijau di kota, (c) Pemanfaatan air, bahan bangunan dan limbah, (d) Kebijakan bidang transportasi, (e) Terkait dengan kesehatan, kenyamanan, ketenteraman dan ketenangan hidup. Beberapa hal tersebut diatas merupakan bagian/komponen dari

*penulis korespondensi 
pendekatan sustainable city yang terbentuk dari berbagai jenis infrastruktur yang telah mengadopsi prinsip-prinsip berkelanjutan. Tujuan dalam penulisan naskah ini adalah untuk mengetahui sejauh mana isu berkelanjutan, yang lebih detil disebut dengan green telah diformulasikan dan diakomodasi dalam infrastruktur perkotaan di Indonesia berikut capainnya.

Prisma Pentagon adalah paradigma pembangunan untuk mencapai visi sustainable city yang memuat lima panduan kerja operasional, social ware (socioware), ecology ware (ecoware), organisation ware (orgware), technology ware (technoware), financial ware (finware) (Nijkamp, 1994).

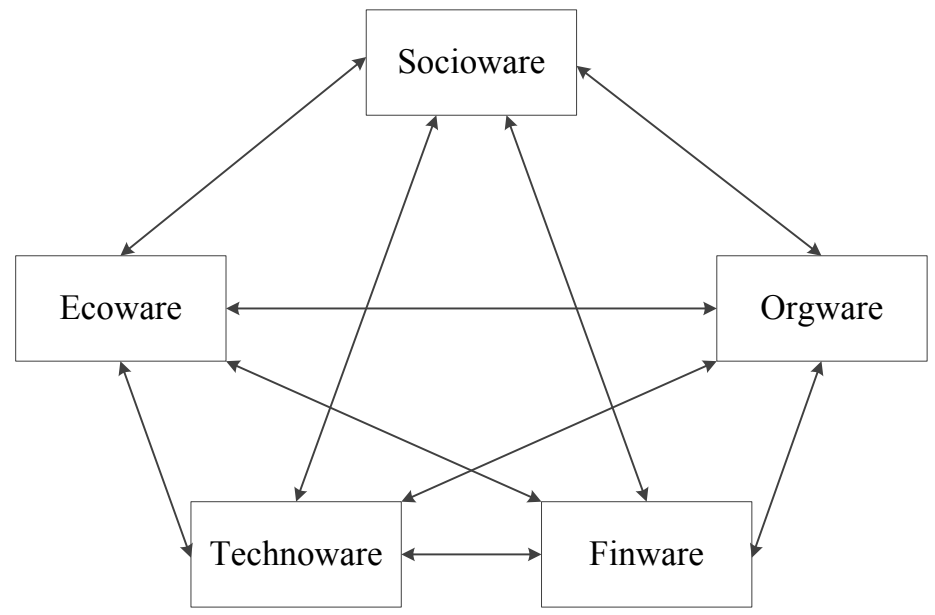

Gambar 1. Prisma Pentagon

Tabel 1. Relasi Antara Socioware, Ecoware, Orgware, Technoware, dan Finware

\begin{tabular}{|l|c|c|c|c|c|}
\cline { 2 - 6 } \multicolumn{1}{c|}{} & Socioware & Ecoware & Orgware & Technoware & Finware \\
\hline Socioware & & Utopianisme & - & - & - \\
\hline Ecoware & Utopianisme & & - & - & Konservasionisme \\
\hline Orgware & - & - & & - & - \\
\hline Technoware & - & - & - & & - \\
\hline Finware & - & Konservasionisme & - & - & \\
\hline
\end{tabular}

Catatan: Utopia adalah sistem sosial politik yang sempurna, hanya ada dalam khayalan dan sulit diwujudkan dalam kenyataan.

Relasi antara ecoware dengan socioware memunculkan pendekatan utopianisme, yaitu memahami persoalan teknologi didasarkan pada perkembangan teknologi yang diimbangi dengan lingkungan alam yang lestari dan kondisi sosial yang tetap terjaga dengan baik. Sedangkan relasi antara ecoware dengan finware memunculkan pendekatan konservasionisme, yaitu pemeliharaan/perlindungan secara teratur guna mencegah timbulnya kerusakan/kemusnahan melalui pelestarian. Pemikir utopia yakin suatu saat keseimbangan antara alam, sosial (kultur manusia), dan teknologi (teknologi komunikasi) dapat terwujud.

\section{Tinjauan Pustaka}

Infrastruktur didefinisikan fasilitas fisik yang mendukung jaringan berbagai jenis fasilitas, berupa jalan raya, jalan kereta api, saluran air bersih, bandar udara, kanal, waduk, tanggul, pengelolahan limbah, perlistrikan, telekomunikasi, pelabuhan laut, dan lainnya. Grigg 
mengkategorisasikan infrastruktur menjadi enam jenis, yaitu: (a) Infrastruktur jalan, (b) Infrastruktur pelayanan transportasi, (c) Infrastruktur air, (d) Infrastruktur manajemen limbah, (e) Infrastruktur bangunan dan fasilitas olah raga luar, (f) Infrastruktur produksi dan distribusi energi (Gambar 1). Dari sejumlah jenis infrastruktur tersebut diatas, belum semuanya terformulasi secara komprehensif yang terkait dengan isu berkelanjutan sebagai isu besarnya. Namun demikian, isu infrastruktur ramah lingkungan yang lebih operasional (sebut "green") di Indonesia telah terformulasi sebagian, diantaranya adalah (a) model assessment green construction untuk bangunan gedung di Indonesia Versi 1.2 yang dikembangkan oleh Ervianto, W.I., 2015. (b) Konstruksi hijau untuk infrastruktur jalan raya yang dikembangkan oleh Puslitbang Jalan (Lawalatta, G., 2013). Beberapa jenis infrastruktur ramah lingkungan yang penelitiannya belum diformulasikan adalah (a) Pelabuhan laut Hijau, (b) Pelabuhan Udara Ramah Lingkungan, (c) Stasiun Kereta api ramah lingkungan.

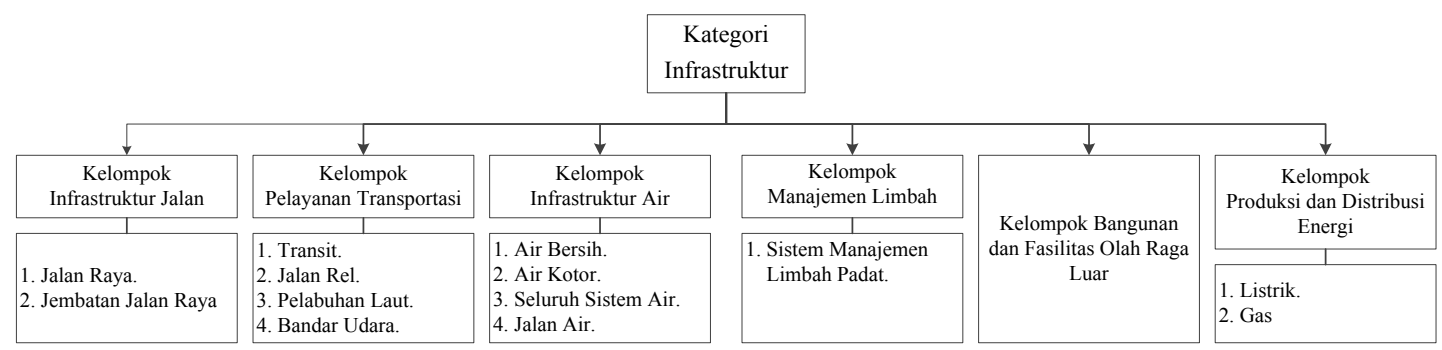

Sumber : Grigg, dalam https://id.wikipedia.org/wiki/Infrastruktur\#Kategori_Infrastruktur, diakses tanggal 7 Juni 2019.

Gambar 2. Kategorisasi Jenis Infrastruktur

Sedangkan penelitian yang dilakukan oleh Ayu (2014) menyatakan bahwa penambahan tumbukan botol kaca sebesar 2,5\% ini dapat menambah kuat tekan beton sebesar 7,57 \% dari kuat tekan beton normal. Namun, penambahan tumbukan botol kaca sebesar 5\% akan mengurangi mutu beton sebesar 3,23 \%, penambahan tumbukan botol kaca sebesar 7,5\% akan mengurangi mutu beton sebesar $11,10 \%$ dan penambahan tumbukan botol kaca sebesar $10 \%$ akan mengurangi mutu beton sebesar $20,02 \%$ dari kuat tekan beton optimum.

\section{Pelabuhan Laut Ramah Lingkungan}

Pendekatan yang digunakan dalam mengakomodasi isu strategis yang terkait dengan aspek sosial, ekonomi, dan lingkungan di tingkat praktis adalah pelabuhan hijau atau green port. Pengetahuan yang menjadi bagian dari isu ini mencakup hal-hal sebagai berikut:

Pertama, pengelolaan peralatan dan fasilitas. Isu dalam kategori ini mencakup: (a) penerapan power management system untuk bangunan, jalan, dan lokasi penyimpanan. (b) pemakaian bahan bakar ramah lingkungan, antara lain Bahan Bakar Gas (BBG) atau Compressed Natural Gas (CNG), (c) pemakaian energi listrik untuk keperluan bongkar muat, (d) tersedianya fasilitas pengumpulan dan pengolahan limbah, (e) pemakaian energi terbarukan, (f) tersedianya gas power plants, (g) penggunaan lampu Light Emitting Diode (LED), (h) penggunaan solar cell sebagai sumber energi, (i) penggunaan freon ramah lingkungan untuk pendingin udara (air conditioning). (j) mengutamakan aspek keselamatan dalam bekerja.

Kedua, penghijauan. Isu dalam persoalan ini mencakup hal-hal sebagai berikut: (a) memenuhi persyaratan Ruang Terbuka Hijau (RTH) dan kewajiban yang terkait dengan lingkungan. (b) tindakan untuk mereduksi polutan. (c) melakukan penghijauan melalui penanaman pohon, misalnya satu karyawan menanan tiga pohon.

Ketiga, aspek lingkungan. Isu dalam hal ini adalah penerapan program lingkungan, yang mencakup: (a) program bina lingkungan, (b) minimalisasi penggunaan kertas di kantor, (c) gerakan hemat energi dan air, (d) menerapkan prinsip reduce, reuse, recycle. (e) mengelola limbah, (f) tersedianya fasilitas 
incinerator, (g) menggunakan Oily Water Separator (OWS) adalah alat yang digunakan untuk memisahkan air dari air buangan yang mengandung minyak sampai hasil pemisahaannya mencapai kurang dari 15 Parts Per Million (PPM).

Selain ketiga hal yang terkait dengan pelabuhan ramah lingkungan tersebut diatas, perlu mempertimbangkan untuk mengakomodasi prinsip pelabuhan cerdas (smart port) berupa otomatisasi di lokasi terminal, antara lain adalah: (a) otomatisasi sistem Combine Terminal Tractor (CTT). (b) gerbang otomatis saat kendaraan masuk maupun keluar dari terminal. (c) Automated Stacking Crane (ASC), dimana satu operator dapat mengoperasikan tiga sampai dengan empat ASC secara bersamaan yang dikendalikan dari menara. (d) menggunakan sistem lift otomatis on/off di docking station. Dengan adanya campur tangan teknologi dan sistem yang efisien maka berpotensi mengurangi dwelling time di pelabuhan. Hal ini secara tidak langsung akan berdampak pada pengurangan biaya logistik dan berpotensi menjaga ketersediaan berbagai komoditas di seluruh wilayah Indonesia.

Tabel 2. Sintesa Isu Pelabuhan Laut Hijau (Green Port)

\begin{tabular}{|c|c|c|c|}
\hline No & Frankel, 1987 & $\begin{array}{l}\text { European Sea Port } \\
\text { Organization, } 2004 .\end{array}$ & $\begin{array}{l}\text { Green Performance Criteria For } \\
\text { Sustainable Ports In Asia, } 2013\end{array}$ \\
\hline 1 & - & - & $\begin{array}{l}\text { Mengurangi kecepatan kapal saat } \\
\text { hendak menepi untuk mengurangi } \\
\text { polusi dan konsumsi bahan bakar }\end{array}$ \\
\hline 2 & - & - & $\begin{array}{l}\text { Menggunakan energi pengganti dan } \\
\text { perangkat hemat energi }{ }^{10}\end{array}$ \\
\hline 3 & - & - & $\begin{array}{l}\text { Mendorong penggunaan bahan bakar } \\
\text { rendah belerang }\end{array}$ \\
\hline 4 & $\begin{array}{l}\text { Mencegah pembuangan } \\
\text { limbah di laut }\end{array}$ & Pembuangan $^{1}$ & - \\
\hline 5 & $\begin{array}{l}\text { Persoalan polusi udara } \\
\text { yang ditimbulkan oleh } \\
\text { muatan kapal yang tidak } \\
\text { dikemas secara baik }^{2}\end{array}$ & Kualitas udara ${ }^{2}$ & $\begin{array}{l}\text { Menghindari polusi udara (regulasi gas } \\
\text { beracun) dengan mengurangi emisi } \mathrm{CO}_{2} \\
\text { kendaraan di jalan dan mendorong } \\
\text { pengembangan moda angkutan umum }\end{array}$ \\
\hline 6 & $\begin{array}{l}\text { Persoalan pencemaran } \\
\text { tumpahan minyak akibat } \\
\text { kebocoran pipa }\end{array}$ & - & - \\
\hline 7 & $\begin{array}{l}\text { Persoalan kebisingan dan } \\
\text { getaran saat proses } \\
\text { pemindahan muatan }\end{array}$ & Kebisingan $^{7}$ & $\begin{array}{l}\text { Memperhatikan peraturan tentang } \\
\text { kebisingan dan getaran yang } \\
\text { ditimbulkan oleh peralatan bongkar }_{\text {muat }^{3} \text { (terganggunya masyarakat saat }} \\
\text { proses konstruksi pelabuhan dan saat } \\
\text { dekonstruksi) }\end{array}$ \\
\hline 8 & Melindungi biota laut ${ }^{5}$ & - & Perlindungan dan kelestarian biota laut ${ }^{4}$ \\
\hline 9 & $\begin{array}{l}\text { Keberlanjutan kehidupan } \\
\text { plankton terkait dengan air } \\
\text { ballast kapal }^{6}\end{array}$ & - & Kontrol polutan air ballast $^{8}$ \\
\hline 10 & $\begin{array}{l}\text { Keberlanjutan flora dan } \\
\text { fauna di sekitar } \\
\text { pelabuhan } 5 \& 6\end{array}$ & - & Pelestarian ekologi dan lingkungan ${ }^{8}$ \\
\hline 11 & - & - & $\begin{array}{l}\text { Menggunakan sumber daya alam yang } \\
\text { dapat didaur ulang dan mengurangi } \\
\text { konsumsi energi }^{9}\end{array}$ \\
\hline 12 & - & $\begin{array}{l}\text { Pengembangan } \\
\text { lahan pelabuhan }\end{array}$ & $\begin{array}{l}\text { Rencana kontingensi/ketidakpastian } \\
\text { terjadinya tumpahan bahan bakar }\end{array}$ \\
\hline 13 & - & Kargo & $\begin{array}{l}\text { Pencegahan dan pengendalian } \\
\text { penumpahan kargo cair }\end{array}$ \\
\hline 14 & - & Pengisian bahan & - \\
\hline
\end{tabular}




\begin{tabular}{|c|c|c|c|}
\hline No & Frankel, 1987 & $\begin{array}{l}\text { European Sea Port } \\
\text { Organization, } 2004 .\end{array}$ & $\begin{array}{l}\text { Green Performance Criteria For } \\
\text { Sustainable Ports In Asia, } 2013\end{array}$ \\
\hline & & bakar & \\
\hline 15 & - & $\mathrm{Debu}^{2}$ & $\begin{array}{l}\text { Pengolahan limbah dan pengendalian } \\
\text { sumber daya air }\end{array}$ \\
\hline 16 & - & Pengerukan $^{9}$ & $\begin{array}{l}\text { Pengelolaan limbah padat hasil proses } \\
\text { pengerukan dan pembuangan sedimen }\end{array}$ \\
\hline 17 & $\begin{array}{l}\text { Sedimen di pintu } \\
\text { pelabuhan dan erosi di } \\
\text { sekitar pantai }{ }^{12}\end{array}$ & $\begin{array}{l}\text { Sampah/limbah } \\
\text { pelabuhan }^{1}\end{array}$ & $\begin{array}{l}\text { Sedimen dipintu masuk pelabuhan dan } \\
\text { pengendalian erosi pantai }{ }^{8}\end{array}$ \\
\hline 18 & - & - & $\begin{array}{l}\text { Menghindari timbulnya polutan saat } \\
\text { pemeliharaan pelabuhan dan } \\
\text { pengelolaan kargo }{ }^{9} \text {. }\end{array}$ \\
\hline 19 & $\begin{array}{l}\text { Punahnya kehidupan } \\
\text { fauna di laut yang } \\
\text { disebabkan karena } \\
\text { operasional pelabuhan dan } \\
\text { pelayaran kapal laut }^{6}\end{array}$ & - & - \\
\hline 20 & $\begin{array}{l}\text { Mencegah terjadinya } \\
\text { tumpahan minyak di laut }^{1}\end{array}$ & - & - \\
\hline 21 & - & - & Menggunakan tenaga listrik $^{2}$ \\
\hline 22 & - & - & $\begin{array}{l}\text { Menghindari penurunan nilai keindahan } \\
\text { karena keberadaan saluran pipa }\end{array}$ \\
\hline 23 & - & $\begin{array}{l}\text { Pembuangan } \\
\text { lambung kapal }^{6}\end{array}$ & - \\
\hline
\end{tabular}

Catatan :

Isu penting versi European Sea Port Organization; Green Performance Criteria For Sustainable Ports In Asia, dan Frankel. Pengelompokan yang terkait dengan isu dalam pelabuhan hijau dibedakan menjadi 12 isu, yaitu : (1) Pencemaran lingkungan, (2) Polusi udara, (3) Polusi suara dan getaran, (4) Pelestarian biota, (5) Pelestarian flora, (6) Pelestarian fauna, (7) Pencemaran kebisingan, (8) Pelestarian lingkungan, (9) Reduce, Reuse, Recycle, (10) Efisiensi energi, (11) Estetika atau keindahan, (12) Erosi.

\section{Pelabuhan Udara Ramah Lingkungan}

Konsep ecological airport atau eco-airport diharapkan dapat berkontribusi mengurangi emisi karbondioksida $\left(\mathrm{CO}_{2}\right)$ di sektor penerbangan sebesar 2\% terhadap perubahan iklim. Upaya mewujudkan eco-airport difokuskan pada pengelolaan bandara ramah lingkungan melalui upaya untuk mengurangi dan mencegah timbulnya dampak negatif yang berasal dari kegiatan operasional bandara terhadap lingkungan di bandara dan sekitarnya. Pendekatan yang digunakan dalam sistem pengelolaan lingkungan didasarkan pada prinsip Reduce, Reuse, dan Recycle. Penerapan Eco-Airport telah ditetapkan dalam Peraturan Direktur Jenderal Perhubungan Udara Nomor: SKEP/124/VI/2009 tentang Pedoman Pelaksanaan Bandar Udara Ramah Lingkungan (Eco-Airport) sehingga setiap pengembangan yang dilakukan di bandara harus mengacu dan berpedoman pada ketentuan tersebut.

Dalam hal pembangunan sarana dan prasarana, diupayakan telah menerapkan prinsip konstruksi hijau yang didasarkan pendekatan lean construction dengan mengedepankan prinsip minimum waste maximum value yang berprinsip hemat sumber daya terutama untuk sumberdaya tak terbarukan. Beberapa faktor yang perlu diperhatikan kualitasnya dalam penerapan konsep Eco-Airport adalah sebagai berikut:

- Kualitas Udara, polusi udara sebagai akibat pengoperasian pesawat, kendaraan termasuk pengoperasian alat sumber panas dan konstruksi. 
- Energi, emisi gas $\mathrm{CO}_{2}$ yang berasal dari listrik, gas, bahan bakar kendaraan/pesawat di bandara berkontribusi secara signifikan terhadap pemanasan global sehingga pengurangan penggunaan energi harus menjadi prioritas yang berkelanjutan.

- Kebisingan dan Getaran, kebisingan dan getaran di bandara yang disebabkan oleh pengoperasian pesawat, kendaraan dan fasilitas lainnya akan menjadi isu tersendiri dari pengelolaan bandara.

- Air, terjadinya polusi air terhadap air tanah dan saluran air yang keluar dari bandara yang diakibatkan oleh penggunaan air dalam jumlah besar.

- Tanah, tumpahan minyak pelumas dan oli dari pesawat maupun kendaraan yang berada di bandara berpotensi menimbulkan polusi tanah.

- Limbah, limbah dan sampah yang berasal dari aktivitas bandara perlu mendapat perhatian dan penanganan yang sesuai dengan karakter limbah dan sampah yang dihasilkan.

- Lingkungan Alamiah, fasilitas bandara yang berada di area bandara secara langsung maupun tidak langsung ikut mempengaruhi kualitas lingkungan alam sekitarnya, sehingga diperlukan program penghijauan.

- Aspek lain, selain aspek fisik lingkungan, aspek non fisik seperti sosial, ekonomi, budaya, dan kesehatan masyarakat sekitar merupakan faktor yang wajib diperhatikan dan turut dijaga kualitasnya sebagai bagian dari lingkungan bandara.

\section{Stasiun Kereta Api Ramah Lingkungan}

Pengelola moda transportasi kereta api perlu menerapkan pendekatan ramah lingkungan mengingat jenis moda transportasi ini mampu mengangkut penumpang relatif banyak. Usaha ini dilakukan agar dapat menjaga kebersihan di lokasi: (a) di lingkungan stasiun kereta api. (b) di sepanjang jalan/jalur kereta api, melalui program tamanisasi dengan menggunakan tanaman yang mampu menyerap emisi yang dihasilkan oleh pembakaran bahan bakar jenis solar oleh mesin diesel yang berada dalam lokomotif, sehingga dapat berkontribusi menjaga lingkungan hidup yang sehat terutama bagi warga yang tinggal di sekitar jalan kereta api. (c) Penggunaan air secara tepat kualitas dan tepat volume. Untuk keperluan toilet dalam rangkaian gerbong kereta api dapat menggunakan air bekas atau air hujan yang dipanen saat hujan. Sedangkan untuk keperluan mencuci gerbong dan lokomotif kereta api diperlukan air dalam volume yang relatif besar karena mencucinya secara manual, untuk itu perlu dipertimbangkan sistem pencuciannya menggunakan mesin yang konsumsi penggunaan airnya relatif sedikit. Terkait dengan penduduk yang bertempat tinggal disekitar jalan kereta api, P.T. KAI wajib memberikan pelayanan terbaik untuk masyarakat dan memberikan kontribusi kepada warga yang bermukim di lingkungan sekitar jalan rel kereta api. selama ini warga yang tinggal di sekitar jalan rel kereta api kerap terimbas polusi suara dan udara, oleh karena itu kewajiban bagi P.T. KAI memberi perhatian secara proporsional dalam wujud Corporate Social Responsibility (CSR).

\section{Komparasi Antar Moda Transportasi}

Merujuk berbagai hal tersebut diatas dalam hal infrastruktur diperkotaan terutama untuk moda transportasi kapal laut, pesawat udara dan kereta api jika dikomparasikan satu sama lain dalam hal konsumsi energi yang diukur berdasarkan kebutuhan bahan bakar per penumpang, pilihan terbaiknya berturut-turut adalah : (a) Kereta api, (b) Pesawat udara, (c) Mobil pribadi, dan (d) sepeda motor. Dalam hal biaya investasi yang dibutuhkan untuk menyediakan infrastruktur moda transportasi kereta api $\pm \mathrm{Rp} 30 \mathrm{~s} / \mathrm{d} 40$ miliar per $\mathrm{km}$ (sumber: https://finance.detik.com/berita-ekonomi-bisnis/d-2577365/ini-ongkos-bikin-rel-katiap-1-kilometer-versi-kemenhub). Dalam perspektif konsumsi bahan bakar untuk berbagai jenis moda transportasi, yaitu Sepeda Motor, Mobil, Pesawat Udara, dan Kereta Api untuk menempuh jarak $1.000 \mathrm{~km}$ maka urutan kebutuhan bahan bakar per penumpang berturut-turut adalah (1) Kereta Api, (2) Pesawat Udara, (3) Mobil, dan (4) Sepeda Motor. Hasil komparasi kebutuhan bahan bakar per satu penumpang diperlihatkan dalam Tabel 3. Dengan demikian 
dapat dinyatakan bahwa sepeda motor membutuhkan 3.562,5 liter bahan bakar untuk menempuh $1.000 \mathrm{~km}$ per penumpang. Sedangkan untuk moda transportasi kereta api membutuhkan 1,14 liter bahan bakar untuk menempuh $1.000 \mathrm{~km}$ per penumpang. Oleh karenanya, penting untuk mempromosikan penggunaan angkutan umum bagi masyarakat dalam menjalankan aktivitasnya.

Tabel 3. Perbandingan Konsumsi Bahan Bakar Per Penumpang/liter Didasarkan Jenis Moda Transportasi

\begin{tabular}{|c|l|c|c|c|}
\hline No. & $\begin{array}{c}\text { Moda } \\
\text { Transportasi }\end{array}$ & $\begin{array}{c}\text { Kapasitas } \\
\text { Angkut } \\
\text { Penumpang }\end{array}$ & $\begin{array}{c}\text { Kebutuhan } \\
\text { Bahan Bakar } \\
\text { (liter) }\end{array}$ & $\begin{array}{c}\text { Kebutuhan } \\
\text { bahan bakar } \\
\text { (liter/penumpang) }\end{array}$ \\
\hline \hline 1 & Sepeda Motor & 2 & $7.125,0$ & $3.562,50$ \\
\hline 2 & Mobil & 6 & $7.932,5$ & $1.322,08$ \\
\hline 3 & Pesawat Udara & 500 & $45.600,0$ & 91,20 \\
\hline \multirow{2}{*}{4} & Kereta Api & 1000 & $1.710,0$ & 1,71 \\
\cline { 3 - 5 } & 1500 & $1.710,0$ & 1,14 \\
\hline
\end{tabular}

catatan : Didasarkan asumsi moda transportasi menempuh perjalanc

$1.000 \mathrm{~km}$.

\section{Kesimpulan}

- Beberapa hal penting dalam merumuskan infrastruktur pelabuhan ramah lingkungan diperoleh 23 isu pelabuhan ramah lingkungan yang dapat diketegorisasikan menjadi 12 isu penting, yaitu : (1) Pencemaran lingkungan, (2) Polusi udara, (3) Polusi suara dan getaran, (4) Pelestarian biota, (5) Pelestarian flora, (6) Pelestarian fauna, (7) Pencemaran kebisingan, (8) Pelestarian lingkungan, (9) Reduce, Reuse, Recycle, (10) Efisiensi energi, (11) Estetika atau keindahan, dan (12) Erosi.

- Isu penting dalam memformulasikan stasiun kereta api ramah lingkungan adalah : (1) lingkungan stasiun kereta api yang ramah lingkungan. (2) Sepanjang jalan/jalur kereta api, melalui program tamanisasi dengan menggunakan tanaman yang mampu menyerap emisi $\mathrm{CO}_{2}$. (3) Penggunaan air secara tepat kualitas dan tepat volume, untuk keperluan toilet dalam rangkaian gerbong kereta api dapat menggunakan air bekas atau air hujan yang dipanen saat hujan. Untuk keperluan mencuci gerbong kereta api, perlu dipertimbangkan sistem pencucian menggunakan mesin yang penggunaan airnya relatif sedikit.

- Dalam pemilihan moda transportasi yang didasarkan pada konsumsi bahan bakar disarankan pemilihannya didasarkan pada tingkat konsumsi bahan bakar per orang, secara berturutan adalah : (1) moda transportasi kereta api, (2) Pesawat Udara, (3) Mobil pribadi, dan (4) sepeda motor.

\section{Daftar Pustaka}

Ervianto, W.I., (2015). Model Assessment Green Construction Untuk Bangunan Gedung Di Indonesia Versi 1.2

Lawalatta, G. (2013). Konstruksi Hijau Untuk Infrastruktur Jalan Raya

Pedoman Pelaksanaan Bandar Udara Ramah Lingkungan. Peraturan Direktur Jenderal Perhubungan Udara Nomor: SKEP/124/VI/2009

Yunus, H. S. (2005). Manajemen Kota Perspektif Spasial. Pustaka Pelajar

Infrastruktur. Diakses dari https://id.wikipedia.org/wiki/Infrastruktur\#Kategori_Infrastruktur

Ongkos Rel KA. Diakses dari https://finance.detik.com/berita-ekonomi-bisnis/d-2577365/ini-ongkosbikin-rel-ka-tiap-1-kilometer-versi-kemenhub 
